\title{
短䋊維強化複合材料の等価剛性予測に対する 不完全接着を考慮した力学モデルの評価
}

\author{
井上 良徳*1, 井川 泰爾*2, 岡部 朋永*3 \\ (2016 年 4 月 14 日受付)
}

\section{Validation of Micromechanics Models Including Imperfect Interfaces for Short Fiber Composites Yoshinori Inoue, ${ }^{* 1}$ Taiji IkAWA ${ }^{* 2}$ and Tomonaga OKABE*3}

(Received April 14, 2016)

\begin{abstract}
Micromechanics models proposed by Nairn et al. and Hashin, which can treat imperfect bonded interfaces between fibers and matrix polymers, are evaluated to utilize the models for predicting accurate deformation of injection molded parts of short fiber reinforced thermoplastics. The treatment of the imperfect interfaces is essential to deal with a difference of the interface conditions which affect mechanical properties of the parts. In contrast, general micromechanics models, such as the Mori-Tanaka (MT) model, are not appropriate because a perfect bonded interface is assumed in the models. For the evaluation of the Nairn-Hashin (NH) models, we first compare the $\mathrm{NH}$ models with the MT model under the condition of the perfect interface. Elastic moduli calculated from the NH models almost agreed with that from the MT model. The NH models are then evaluated by using elastic moduli measured for randomly fiber-oriented films of short glass fiber reinforced polypropylene. By considering the imperfect interface parameters estimated from pull-out tests of a single glass fiber embedded in a polypropylene matrix, the $\mathrm{NH}$ models predicted the measured elastic moduli.
\end{abstract}

Key words: Micromechanics model, Imperfect bonded interface, Short fiber composite, Model validation, Mechanical property

\section{1. 緒 \\ $\overline{\overline{\bar{一}}}$}

自動車産業の分野では，燃費向上および環境負荷低減 の要請に伴って, 車体の軽量化が進められている1). 軽量 化に当たっては，金属材料を樹脂系の繊維強化複合材料 に代替することが盛んに行われ, 適用部材に応じて多様 な材料系と成形方法が検討されている ${ }^{21}$. その中でも, 構造部材のように高強度, 高弾性率を必要としない部品

\footnotetext{
*1,*2 (株) 豊田中央研究所 材料・プロセス 2 部 (480-1192 愛知県長久手市横道 41-1)

Material \& Processing Department II, Toyota Central R\&D Labs., Inc.

*1 主任研究員 Senior Researcher, *2 室長 Research Manager

*3 東北大学大学院工学研究科 教授

Professor, Department of Aerospace Engineering, Tohoku University
}

類に対しては, その優れた成形効率と複雑形状への適用 の良さから, 熱可塑性樹脂を短繊維（通常, 数 $\mathrm{mm}$ 以 下）で強化した複合材料を用いた射出成形法が多く使わ れる。

しかし, 射出成形では, 成形品内の部位ごとで成形加 工時に材料が受ける熱や流動の履歴が異なり，それによ り母材樹脂の結晶状態や繊維の配向状態が異なるものと なる ${ }^{3 \sim 5)}$. このため, 成形品内では, 弾性率などの力学特 性とその異方性が部位ごとで異なり，分布が生じる。ま た，繊維の表面処理の違い，つまり界面状態の違いによ つても力学特性は影響を受ける ${ }^{6,7)}$. そこで, 射出成形し た複合材料の変形解析を精度よく行うためには，上記の 力学特性の分布や界面状態の違いを考慮することが重要 である。一般に, 有限要素法などを使って部品等の変形 解析を行う場合は，材料を均質体として，その等価剛性 を用いて解析を行うことが多い. そこで, 力学特性の分 
布や界面状態の違いを考慮して等価剛性を予測できる力 学モデルが必要となる。

Tucker $ら^{8)}$ は, 短瀻維が一方向に揃った複合材料 $($ 一 方向材料）の等価剛性の予測に対して，主要な力学モデ ルの評価を行い, Mori-Tanaka 理論 ${ }^{9}$ 扔よび Lielens ら のモデル10) が優れていることを報告している.しかし， Tucker らが評価したモデルも含め, これまでに提案さ れた多くの力学モデルは, 繊維と母材の 2 相のみを扱 い, 界面にて完全接着を仮定している。このため, 母材 樹脂や繊維の力学特性の違いは考慮できるが, 界面状態 の違いを扱うことができない.

界面状態の違いを扱うため, Zhao と Weng ${ }^{11)}$ おょび Fitoussi ら ${ }^{12)}$ は, Mori-Tanaka 理論とその基礎となる Eshelby の等価介在物法 ${ }^{13)}$ を用いて, 界面の接着性の違 いを考慮できる力学モデルを提案した。しかし，これら のモデルでは, 繊維端にて界面接着性の違いが考慮され ていないなど, 短繊維の複合材料に対しては適さない仮 定が使われている.Jain ら ${ }^{14)}$ はこの仮定を見直し, 短繊 維材料に適用できるモデルを報告している。しかしなが ら，Nairn ら ${ }^{15)}$ は界面接着性の違い（不完全接着）を考 慮した場合, 繊維内の応力分布が不均一になり, 等価介 在物法を適用する前提条件が満たされなくなると主張し ている.そして, shear-lag 法に基づき, 不完全接着を考 慮できる力学モデルを提案した。

そこで本研究では, 短繊維強化の熱可塑性樹脂複合材 料の等価剛性予測に対して, Nairn らの力学モデルを取 り上げ，その予測性能を評価する。なお，Nairnらのモデ ルでは一方向材料における繊維軸方向の縦弾性率しか得 られない. そこで, 縦弾性率以外の弾性特性は, 連続繊

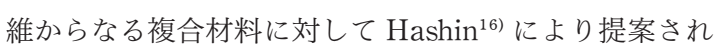
た力学モデルを用い, 両モデルによる等価剛性の予測性 能を評価する。そして, これらの力学モデルにより, 不 完全接着を考慮した短繊維強化複合材料の等価剛性予測 が可能かを検討する。

\section{2. 不完全接着考慮のカ学モデル}

長さ $l_{\mathrm{f}}$, 半径 $r_{\mathrm{f}}$ の繊維が母材樹脂中に体積分率 $V_{\mathrm{f}}$ で分 散し, 全ての繊維が一方向に揃った状態を考える. Nairn らは shear-lag 法に基づいた力学モデルを提案し,この 状態の繊維軸方向の縦弾性率 $E_{\mathrm{A}}$ を次式で表した。

$$
E_{\mathrm{A}}=E_{2} /\left[1+\left(\frac{E_{\mathrm{f}}}{E_{\mathrm{m}}}-1\right)\left(V_{1}-V_{\mathrm{f}}\right)+\frac{E_{\mathrm{f}} V_{\mathrm{f}}}{E_{\mathrm{m}} V_{\mathrm{m}}} \Lambda(\rho)\right]
$$

ここで, $E$ は縦弾性率, $V$ は体積分率を表し, 添え字 $\mathrm{f}$, $\mathrm{m}$ はそれぞれ繊維および母材樹脂を表す。さらに， $E_{2}=E_{\mathrm{f}} V_{1}+E_{\mathrm{m}} V_{2}, \quad V_{1}=\frac{r_{\mathrm{f}}^{2}}{\left(r_{\mathrm{f}}+\Delta\right)^{2}}, \quad V_{2}=1-V_{1}$, $\left(r_{\mathrm{f}}+\Delta\right)^{2}\left(\rho r_{\mathrm{f}}+\Delta\right)=\frac{\rho r_{\mathrm{f}}^{3}}{V_{\mathrm{f}}}$,

$\Lambda(\rho)=\frac{V_{\mathrm{m}}}{V_{2}} \frac{\frac{E_{2}}{E_{\mathrm{f}}} \frac{\mathrm{t} 1}{\beta_{1} \rho}+\left\{1+\left(1-\frac{E_{2}}{E_{\mathrm{f}}}\right)^{2} \frac{\mathrm{t} 1}{\beta_{1} \eta}\right\} \frac{\mathrm{t} 2}{\beta_{2} \rho}}{1+\frac{\mathrm{t} 1}{\beta_{1} \eta}+\frac{E_{2}}{\eta E_{\mathrm{f}}} \frac{\mathrm{t} 2}{\beta_{2}}}$,

$\mathrm{t} 1=\tanh \left(\beta_{1}^{*} \rho\right), \mathrm{t} 2=\tanh \left(\beta_{2} \rho\right)$

$\beta_{1}^{2}=-\frac{4 G_{\mathrm{m}} V_{2}}{E_{\mathrm{m}}\left(V_{2}+\ln V_{1}\right)}$,

$\beta_{2}^{2}=\frac{\frac{4 E_{2}}{E_{\mathrm{f}} E_{\mathrm{m}}}}{\frac{V_{2}}{2 G_{\mathrm{f}}}-\frac{1}{G_{\mathrm{m}}}\left(\frac{V_{2}}{2}+1+\frac{\ln V_{1}}{V_{2}}\right)+\frac{2 V_{2}}{r_{\mathrm{f}} D_{\mathrm{t}}}}$,

$\beta_{1}^{*}=\frac{\left(V_{1}-V_{\mathrm{f}}\right) \beta_{1}}{2 V_{\mathrm{f}}}, \eta=\frac{E_{\mathrm{m}} V_{2}}{\gamma_{\mathrm{f}} D_{\mathrm{n}}}$

であり, $G$ はせん断弾性率, $\rho$ は繊維のアスペクト比( $\left.l_{\mathrm{f}} / 2 \gamma_{\mathrm{f}}\right)$ を表す.また, 本研究では, 繊維および母材樹脂 は等方性を仮定し, $G=E /\{2(1+\nu)\}$ の関係を用いた。こ こで, $\nu$ はポアソン比である.

さて, Nairn らの力学モデルでは, 繊維と母材の界面 は仮想的なばねで繫がれているとして, そのばね定数 $D_{\mathrm{t}}, D_{\mathrm{n}}$ により界面でのずれやすさを表す。そして， $D_{\mathrm{t}}$ は 界面が繊維軸方向にせん断変形を受ける場合のばね定数 であり， $D_{\mathrm{n}}$ は界面がその法線方向に引張変形を受ける 場合のばね定数である.さらに後述されるが， $D_{\mathrm{s}}$ は界面 が繊維の円周に沿ってせん断変形を受ける場合の值であ る.

纎維が一方向に揃った状態を横等方性体と仮定する と, その力学特性を表すためには, $E_{\mathrm{A}}$ 以外に 4 つの弾性 特性が必要である。 $E_{\mathrm{A}}$ 以外は繊維長による影響が少な いことが報告されている ${ }^{15)}$ ので,ここでは連続繊維を対 象に Hashinより提案された力学モデルを用いた. 本モ デルは, 全ての繊維が一方向に揃った複合材料にて不完 全接着がある場合の力学特性を一般化 self-consistent 法 によりモデル化したものであり，不完全接着を仮想ばね で表す手法は元来 Hashin が提案したものである. 本モ デルにより, 体積弾性率 $K$, 縦方向ポアソン比 $\nu_{\mathrm{A}}$ 抢よ び縦方向せん断弾性率 $G_{\mathrm{A}}$ は次のように表される。

$$
K=K_{\mathrm{m}}+\frac{V_{\mathrm{f}}}{\frac{1}{K_{\mathrm{e}}-K_{\mathrm{m}}}+\frac{V_{\mathrm{m}}}{K_{\mathrm{m}}+G_{\mathrm{m}}}}
$$




$$
\begin{aligned}
& \nu_{\mathrm{A}}=\nu_{\mathrm{m}} V_{\mathrm{m}}+\nu_{\mathrm{f}} V_{\mathrm{f}}+\frac{\left(\nu_{\mathrm{f}}-\nu_{\mathrm{m}}\right)\left(\frac{1}{K_{\mathrm{m}}}-\frac{1}{K_{\mathrm{e}}}\right) V_{\mathrm{m}} V_{\mathrm{f}}}{\frac{V_{\mathrm{m}}}{K_{\mathrm{e}}}+\frac{V_{\mathrm{f}}}{K_{\mathrm{m}}}+\frac{1}{G_{\mathrm{m}}}} \\
& G_{\mathrm{A}}=G_{\mathrm{m}}+\frac{V_{\mathrm{f}}}{\frac{1}{G_{\mathrm{e}}-G_{\mathrm{m}}}+\frac{V_{\mathrm{m}}}{2 G_{\mathrm{m}}}}
\end{aligned}
$$

$$
\text { ここで， }
$$

$$
K_{\mathrm{e}}=\frac{K_{\mathrm{f}}}{1+\frac{2 K_{\mathrm{f}}}{r_{\mathrm{f}} D_{\mathrm{n}}}}, \quad G_{\mathrm{e}}=\frac{G_{\mathrm{f}}}{1+\frac{2 G_{\mathrm{f}}}{\gamma_{\mathrm{f}} D_{\mathrm{t}}}}
$$

である.また，横方向せん断弾性率 $G_{\mathrm{T}}$ は次式より得ら れる。

$$
D\left(g^{*}\right)=\left|\begin{array}{cccccccc}
1 & -1 & 1 & 1 & 1 & 1 & 0 & 0 \\
1 & 1 & \frac{2+\xi_{\mathrm{m}}}{1-\xi_{\mathrm{m}}} & 1 & \frac{\xi_{\mathrm{m}}}{1+\xi_{\mathrm{m}}} & -1 & 0 & 0 \\
g^{*} & 3 g^{*} & 0 & 1 & -\frac{2}{1+\xi_{\mathrm{m}}} & -3 & 0 & 0 \\
g^{*} & -3 g^{*} & \frac{3}{1-\xi_{\mathrm{m}}} & 1 & \frac{1}{1+\xi_{\mathrm{m}}} & 3 & 0 & 0 \\
0 & 0 & 0 & 1 & -\frac{2}{\left(1+\xi_{\mathrm{m}}\right) V_{\mathrm{f}}} & -3 / V_{\mathrm{f}}^{2} & 0 & -\frac{G_{\mathrm{f}}}{G_{\mathrm{m}}} \\
0 & 0 & \frac{3 V_{\mathrm{f}}}{1-\xi_{\mathrm{m}}} & 1 & \frac{1}{\left(1+\xi_{\mathrm{m}}\right) V_{\mathrm{f}}} & 3 / V_{\mathrm{f}}^{2} & -\frac{3 G_{\mathrm{f}} V_{\mathrm{f}}}{\left(1-\xi_{\mathrm{f}}\right) G_{\mathrm{m}}} & -\frac{G_{\mathrm{f}}}{G_{\mathrm{m}}} \\
0 & 0 & V_{\mathrm{f}} & 1 & 1 / V_{\mathrm{f}} & 1 / V_{\mathrm{f}}^{2} & -V_{\mathrm{f}} & -(p+1) \\
0 & 0 & \frac{\left(2+\xi_{\mathrm{m}}\right) V_{\mathrm{f}}}{1-\xi_{\mathrm{m}}} & 1 & \frac{\xi_{\mathrm{m}}}{\left(1+\xi_{\mathrm{m}}\right) V_{\mathrm{f}}} & -1 / V_{\mathrm{f}}^{2} & -\frac{\left(3 q+2+\xi_{\mathrm{f}}\right) V_{\mathrm{f}}}{1-\xi_{\mathrm{f}}} & -(q+1)
\end{array}\right|=0
$$

ここで,

$g^{*}=\frac{G_{\mathrm{T}}}{G_{\mathrm{m}}}, \quad \xi_{\mathrm{m}}=\frac{G_{\mathrm{m}}}{K_{\mathrm{m}}}, \quad \xi_{\mathrm{f}}=\frac{G_{\mathrm{f}}}{K_{\mathrm{f}}}, \quad p=\frac{2 G_{\mathrm{f}}}{r_{\mathrm{f}} D_{\mathrm{n}}}, \quad q=\frac{2 G_{\mathrm{f}}}{r_{\mathrm{f}} D_{\mathrm{s}}}$

である。（5)式は $g^{*}$ に関する以下の 2 次式となることか ら, その係数を(7)式より求め, (6) 式を解くことで, $g^{*}$ すなわち $G_{\mathrm{T}}$ が求められる枮. なお，行列式 $D$ の計算に はガウスの消去法を用いた。

$$
\begin{gathered}
D\left(g^{*}\right)=A g^{* 2}+2 B g^{*}+C=0 \\
\left\{\begin{array}{l}
A=\frac{1}{2}[D(1)+D(-1)]-D(0), \\
B=\frac{1}{4}[D(1)-D(-1)], \\
C=D(0)
\end{array}\right.
\end{gathered}
$$

本モデルの適用においても，緎維㧍よび母材樹脂は等方 性を仮定し， $G=E /\{2(1+\nu)\}$ おょび $K=G /(1-2 \nu)$ の 関係を用いた。

以上より，横等方性体の剛性マトリックスは，上記で 得られた 5 つの弾性特性より次で表される. (8)式にて, 座標軸 1 は繊維の配向方向で, 座標軸 2,3 はそれに垂直 な方向である。また， $\sigma, \tau$ は応力， $\varepsilon, \gamma$ はひずみを表す。

$$
\left\{\begin{array}{c}
\sigma_{1} \\
\sigma_{2} \\
\sigma_{3} \\
\tau_{23} \\
\tau_{31} \\
\tau_{12}
\end{array}\right\}=\left\{\begin{array}{cccccc}
Q_{11} & Q_{12} & Q_{12} & 0 & 0 & 0 \\
Q_{12} & Q_{22} & Q_{23} & 0 & 0 & 0 \\
Q_{12} & Q_{23} & Q_{22} & 0 & 0 & 0 \\
0 & 0 & 0 & \frac{1}{2}\left(Q_{22}-Q_{23}\right) & 0 & 0 \\
0 & 0 & 0 & 0 & Q_{66} & 0 \\
0 & 0 & 0 & 0 & 0 & Q_{66}
\end{array}\right\}\left\{\begin{array}{c}
\varepsilon_{1} \\
\varepsilon_{2} \\
\varepsilon_{3} \\
\gamma_{23} \\
\gamma_{31} \\
\gamma_{12}
\end{array}\right\}
$$

ここで

$Q_{11}=E_{\mathrm{A}}+4 K \nu_{\mathrm{A}}^{2}, \quad Q_{22}=K+G_{\mathrm{T}}, \quad Q_{66}=G_{\mathrm{A}}$

$Q_{12}=2 K \nu_{\mathrm{A}}, \quad Q_{23}=K-G_{\mathrm{T}}$

である.

Nairn ら拈よび Hashin の力学モデル (以後, 両者を合 わせて Nairn-Hashin モデルと呼ぶ）の評価に当たっ て, 本研究ではガラス短繊維がランダム配向したフィル ム状試験片を用いて引張試験を行った（詳細は後述す る)。そこで, 本試験より得られる弾性率との比較を行う ため, 次の手順により, ランダム配向したフィルムに対 応する弾性率を求めた。

まず，フィルム状試料であることから，平面応力状態 を仮定すると，剛性マトリックスは次のようになる。 


$$
\left\{\begin{array}{l}
\sigma_{1} \\
\sigma_{2} \\
\tau_{12}
\end{array}\right\}=\left\{\begin{array}{ccc}
Q_{11} & Q_{12} & 0 \\
Q_{12} & Q_{22} & 0 \\
0 & 0 & Q_{66}
\end{array}\right\}\left\{\begin{array}{c}
\varepsilon_{1} \\
\varepsilon_{2} \\
\gamma_{12}
\end{array}\right\}
$$

そして，フィルムの面内に $x-y$ 座標系を考え， $x$ 座標が 繊維の配向方向から $\theta$ だけ傾いているとすると，(9)式 の座標変換より次式が得られる。

$$
\left\{\begin{array}{c}
\sigma_{x} \\
\sigma_{y} \\
\tau_{x y}
\end{array}\right\}=\left\{\begin{array}{lll}
\bar{Q}_{11} & \bar{Q}_{12} & \bar{Q}_{16} \\
\bar{Q}_{12} & \bar{Q}_{22} & \bar{Q}_{26} \\
\bar{Q}_{16} & \bar{Q}_{26} & Q_{66}
\end{array}\right\}\left\{\begin{array}{c}
\varepsilon_{x} \\
\varepsilon_{y} \\
\gamma_{x y}
\end{array}\right\}
$$

ここで,

$$
\left\{\begin{array}{l}
\bar{Q}_{11} \\
\bar{Q}_{12} \\
\bar{Q}_{22} \\
\bar{Q}_{16} \\
\bar{Q}_{26} \\
\bar{Q}_{66}
\end{array}\right\}=\left\{\begin{array}{cccc}
c^{4} & 2 c^{2} s^{2} & s^{4} & 4 c^{2} s^{2} \\
c^{2} s^{2} & c^{4}+s^{4} & c^{2} s^{2} & -4 c^{2} s^{2} \\
s^{4} & 2 c^{2} s^{2} & c^{4} & 4 c^{2} s^{2} \\
c^{3} s & c s^{3}-c^{3} s & -c s^{3} & 2\left(c s^{3}-c^{3} s\right) \\
c s^{3} & c^{3} s-c s^{3} & -c^{3} s & 2\left(c^{3} s-c s^{3}\right) \\
c^{2} s^{2} & -2 c^{2} s^{2} & c^{2} s^{2} & \left(c^{2}-s^{2}\right)^{2}
\end{array}\right\}\left\{\begin{array}{l}
Q_{11} \\
Q_{12} \\
Q_{22} \\
Q_{66}
\end{array}\right\},
$$

$c=\cos \theta, \quad s=\sin \theta$

である。そして，繊維長分布㧍よび繊維配向分布を考慮 した複合材料全体としての剛性マトリックス $A_{i j}$ は, laminate analogy approach ${ }^{17)}$ を適用し, 次で表される。

$$
A_{i j}=\int_{0}^{\pi} \int_{l_{\min }}^{l_{\max }} \bar{Q}_{i j} \psi(l) \phi(\theta) d l d \theta
$$

ここで， $\psi(l)$ は繊維長分布の確率密度関数で, $\phi(\theta)$ は 繊維配向分布の確率密度関数である.ランダム配向の場 合， $\phi(\theta)$ は全ての角度 $\theta$ で同じ值を用いる。これより, 実測に対応する弾性率 $E_{x x}$ は, 次のように表される。

$$
E_{x x}=\frac{A_{11} A_{22}-A_{12}^{2}}{A_{22}}
$$

\section{3. 検 証 実 験}

\section{1 供試材料}

検証で用いた樹脂は, ガラス繊維強化ポリプロピレン (モストロン L-2040P，プライムポリマー)である. 本樹 脂には, 長さ $8 \mathrm{~mm}$ のガラス繊維 $(\mathrm{GF})$ 束に $50 \mathrm{wt} \%$ の ポリプロピレン (PP) が含浸した長繊維 PP ペレットと $\mathrm{PP}$ 単体ペレットが混じっており, 全体で $\mathrm{GF}$ 含有率が $20 \mathrm{wt} \%$ となっている. 検討では，母材樹脂の特性を調 べるために，PP 単体ペレットのみの材料も用意した. GF 入りの材料については, GF を材料中に均一分散さ
せるために，混練・押出成形評価試験装置ラボプラスト ミル（10C100，東洋精機製作所）を用いて混練した。混 練時間は 5 分間で, その時の樹脂温度とローター回転数 は繊維長が異なる材料を作製する目的で 2 条件を採用し た。それらは, 条件 $1\left(190^{\circ} \mathrm{C}, 100 \mathrm{rpm}\right)$ と条件 $2\left(220^{\circ} \mathrm{C}\right.$, $25 \mathrm{rpm}$ ) である. なお, 本混練条件が母材樹脂の劣化 (分 子量低下）に及ぼす影響は, 混練温度が樹脂の熱分解温 度 ${ }^{18)}$ よりも十分低く, かつローター回転によるせん断速

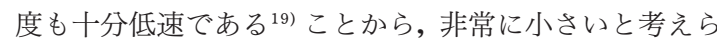
れる。

\section{2 繊維長測定}

上記で作製した $\mathrm{GF}$ 入り材料をるつぼに入れ， $600^{\circ} \mathrm{C}$ のホットプレート上で 1 時間加熱して, 樹脂成分を完全 に燃焼させた。残った緎維をシャーレ上に広げた上で拡 大画像を実体顕微鏡で撮影し, 画像解析装置 (LUZEX$\mathrm{AP}$, ニレコ）により䋊維長分布を測定した。

\section{3 試験片作製}

準備した材料それぞれについて, 熱履歴の異なる 2 水 準のフィルムをプレス成形により作製した。作製方法 は, まず 2 枚のステンレス板に材料とスペーサー（板厚 $0.1 \mathrm{~mm}$ ）をはさみ, $220^{\circ} \mathrm{C}$ の熱プレスにて 4 分間溶融す る.その後, $28^{\circ} \mathrm{C}$ に保持した冷プレスにステンレス板ご とすばやく移動して 4 分間保持し, 急冷フィルムを作製 した。一方, 同様の溶融後, 熱プレスょり取り出したス テンレス板を室温中に放置して徐冷フィルムを作製し た。徐冷中の温度は，ステンレス板表面を接触温度計て 測定した結果, 40 分で $41^{\circ} \mathrm{C}$ まで低下したことから, 40 分 後にステンレス板よりフィルムを取り出した. 引張試験 で用いるダンベル形試験片（JIS K7162-1994 5A 形）は 上記で作製したフィルムを打ち抜き作製した。なお，フ ィルム厚さの $0.1 \mathrm{~mm}$ は, 厚み方向での不均一性を避け るために採用した ${ }^{20)}$.

\section{4 引張試験}

前節で作製したダンベル形試験片を用いて引張試験を 行った．試験機は万能試験機（5566，インストロン）で あり, 引張速度を $1 \mathrm{~mm} / \mathrm{min} と し て, n=5$ で測定した。 標線間ひずみは，一部の試験片を用いたビデオ伸び計に よる計測と市販の構造解析ソフト (ABAQUS, ダッソー システムズ）を用いた解析の両者より，ストロークから 求めたひずみの 1.25 倍であった。そこで，ひずみ量はス トロークから求めたひずみを 1.25 倍して算出した. 弾性 率は得られた公称応力一公称ひずみ曲線より, ひずみが $0.2 \%$ と $0.3 \%$ の応力值を用いて求めた. 


\section{5 繊維配向観察}

GF を含む急冷フィルムについては, X線 CT 装置(TDM$1000 \mathrm{H}-\mathrm{II}$ ，ヤマト科学)を用いた 2 次元スキャンにより, 板厚方向全域に渡る繊維配向状態を観察した。

\section{6 結晶化度測定}

$\mathrm{PP}$ の急冷および徐冷フィルムについて，結晶化度を 測定した。測定方法は，DSC (示差走査熱量計，Q1000, TA インスツルメント) により融解熱を測定し，完全結 晶での融解熱 $209 \mathrm{~J} / \mathrm{g}^{21)}$ との比を取ることで求めた。な お， GF が核剤として PP の結晶化に作用する能力は小 さく ${ }^{22)}$, さらに GF の含有率も $8 \mathrm{vol} \%$ (20 wt \%) と低い ことから，結晶化度に対する GF の影響は非常に小さい と考えられる。

\section{4. 結 果と考 察}

試験片作製時の急冷条件および徐冷条件の妥当性を見 るために，結晶化度を測定した。測定した結晶化度は急 冷サンプルにて $56.8 \%$ ，徐冷サンプルにて $61.0 \%$ あっ た. PP は成形時の冷却条件によって結晶化度が異なり, その範囲は 55〜 65\% と報告されている ${ }^{23)}$. 今回得られた 值はその範囲に入り，それぞれが上限および下限寄りの 值となっていることから，今回のサンプル作製条件は成 形時の急冷および徐冷を模擬した条件になっていると考 える。

繊維長の測定結果を Fig. 1 に示す. 条件 1 に対して, 条件 2 は混練が弱い条件であるため, 繊維長が長く保た れていることが分かる。体積平均繊維長は条件 1 で 1.01 $\mathrm{mm}$ ，条件 2 で $3.00 \mathrm{~mm}$ であった。そこで，以後の説明 では条件 1 の材料をPPGF-S とし，条件 2 の材料を PPGF-L とする. 両材料を用いた急冷フィルムの X 線 CT による䋊維配向の観察結果を Fig. 2 に示す.フィル ム厚が $0.1 \mathrm{~mm}$ に対して繊維長が 1 ～ $3 \mathrm{~mm}$ であるため にほぼ面内配向と考えられるが，Fig. 2 よりいずれの材 料でも GF は面内のあらゆる方向を向き，面内でのラン ダム配向が実現されていることが分かる。

さて，実測值との比較による Nairn-Hashin モデルの 評価に先立ち，他の力学モデルとの比較を行った。対象 としたモデルは Mori-Tanaka 理論である.このため に，Nairn-Hashin モデルの計算では，界面での完全接 着 $\left(1 / D_{\mathrm{t}}=1 / D_{\mathrm{n}}=1 / D_{\mathrm{s}}=0\right)$ を仮定した。両モデルの計 算に当たっては，母材 PP の弾性率は実測值（後述の Fig. 3 に記載）を用い，GF の弾性率および PP と GF の ポアソン比はそれぞれ $72 \mathrm{GPa}, 0.35,0.22$ を用いた ${ }^{24,25)}$. また，GF の直径は実測の $0.015 \mathrm{~mm}$ とした. 比較結果を
Fig. 3 に示す.ここで, 実測值の表示では棒グラフにより 平均值を示し, 標準偏差をエラーバーで示した. Fig. 3 よ り，Nairn-Hashin モデルにて完全接着を仮定した結果 は, Mori-Tanaka 理論の結果とほぼ同等であることが 分かる. 一方, 実測值と比べると, 両モデルとも高い弾 性率を示している。この違いについては，次のように考

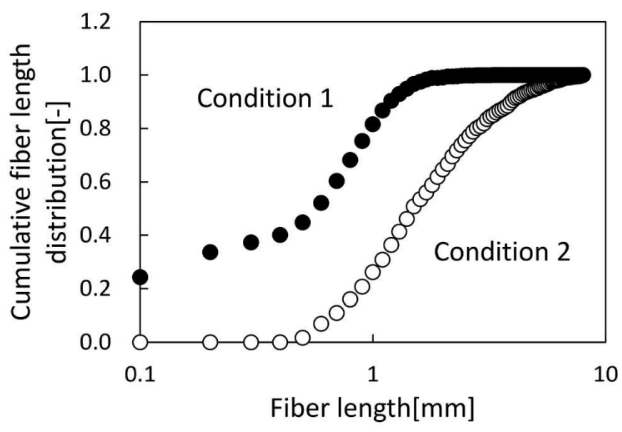

Fig. 1 Fiber length distributions.

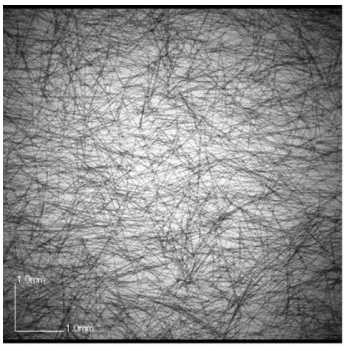

PPGF-S

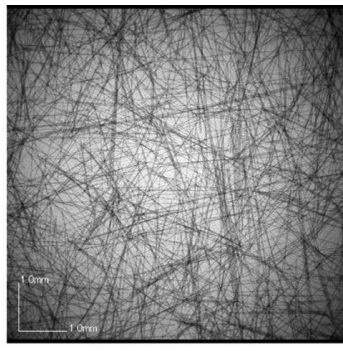

PPGF-L
Fig. 2 X-ray transmission images for fiber orientation measurements.

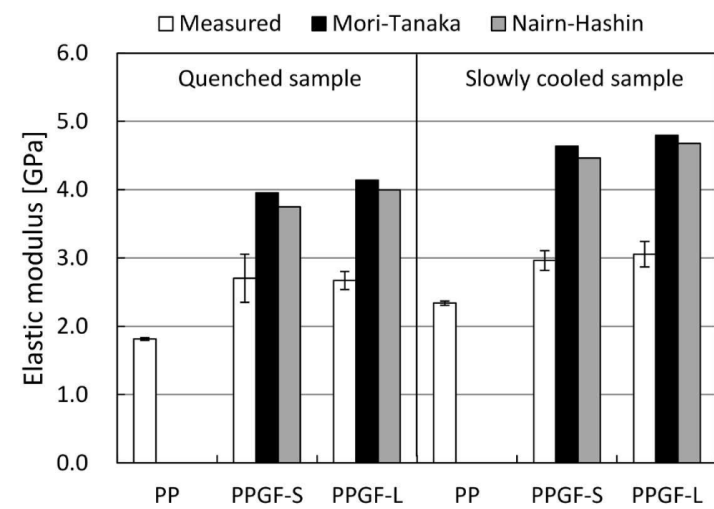

Fig. 3 Comparison of measured and calculated elastic moduli. The calculated ones are obtained under the assumption of perfect bonded interfaces. 
- Mori-Tanaka (Distribution) $\boxminus$ Mori-Tanaka (Averaged) $\square$ Nairn-Hashin (Distribution) $\backsim$ Nairn-Hashin (Averaged)

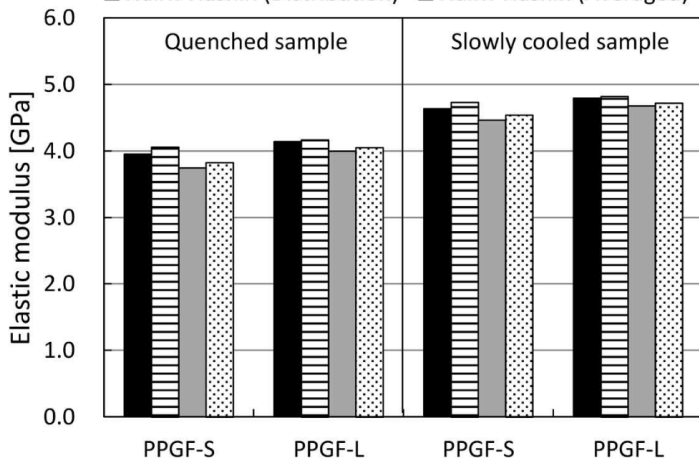

Fig. 4 Comparison of elastic moduli calculated using fiber length distributions and averaged fiber lengths.

える。まず，PP 単体では $2 \mathrm{GPa}$ 前後の弾性率が測定さ れ，さらに一般の PP の弾性率が $1 \sim 2 \mathrm{GPa}$ 程度である ことから, 弾性率の測定自体には大きな問題はないと考 えている。一方，今回用いた樹脂ペレットは，通常，射 出成形で用いられるものである。このため, サンプル作 製に用いたプレス成形では, 射出成形の保圧過程に相当 する樹脂収縮時の加圧が充分でないために，樹脂と繊維 の界面接着が十分に確立されず，低い弾性率が測定され たと考えられる。

次に, 界面での完全接着の仮定のまま, 繊維長分布を 考慮した場合と考慮せずに平均繊維長を用いた場合の比 較を行った。その結果を Fig. 4 亿示す。これより，いず れのモデルでも平均值を用いた場合に弾性率はわずかに 高くなるが，今回のサンプルでは大きな違いがないこと が分かった。なお，以後の評価では，計算の正確性を上 げるために,全ての計算は纎維長分布を考慮して行った。

さて，Fig. 3 での考察より，実サンプルでは樹脂と繊 維の界面にて接着の不完全性が懸念された。そこで, Nairn-Hashin モデルを用いて，不完全接着を考慮した 弾性率予測を試みた。先に述べたように，本モデルでは 界面を仮想ばねで繫ぎ，変形方向に応じてそのばね定数 を与えることで，各方向への界面のすべりやすさを表し ている，このため，方向に応じたばね定数の值が必要と なるが，これらの実測值は著者の知る限り報告されてい ない。一方，単繊維を使ったプルアウト試験やマイクロ ボンド試験により，繊維の引き抜き量に対するせん断応 力の関係が測定されている。この試験は界面せん断強度 の測定を主目的にしたものであるが，見方を変えれば， 界面に設置した仮想ばねを引き抜き方向に引張り，その $\square$ Measured $\square$ Nairn-Hashin

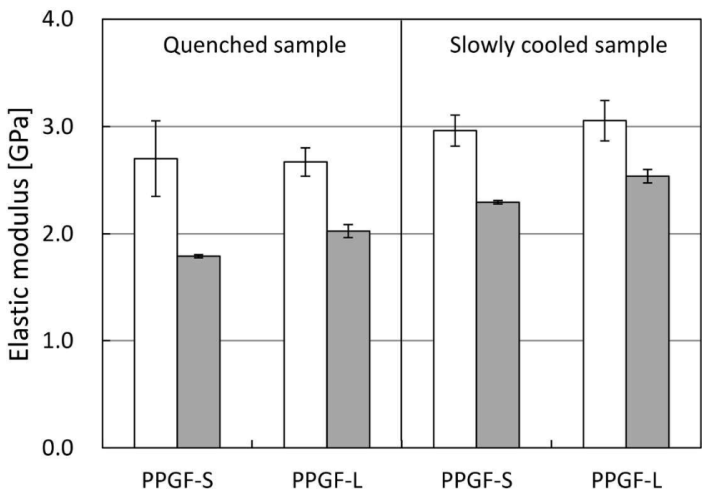

Fig. 5 Comparison of measured and calculated elastic moduli. The calculated ones are obtained using imperfect interface parameters.

時の応力つまり単位面積当たりのばね定数を測定してい ると考光ることもできる. Yang ら ${ }^{26)}$ およびMader ら ${ }^{27)}$ は， ポリプロピレンとガラス単繊維を対象にせん断応力ー引 き抜き量曲線を測定した。そこで，この曲線の直線部分 の傾きより，上記のばね定数に相当する值 $(0.05 \sim 0.1$ $\mathrm{GPa} / \mathrm{mm}$ ) を求め, その值を Nairn-Hashin モデルの 3 つのばね定数に共通に用いて計算を行った。

不完全接着を考慮した弾性率計算の結果を Fig. 5 に 示す。ここで, 計算值のエラーバーはばね定数の幅 （0.05 0.1 GPa $/ \mathrm{mm})$ を表す.これより，完全接着を仮 定した時は, Fig. 3 に示したように弾性率の計算值は実 測值よりも大きな值を示したが，Fig. 5 の結果では逆に 計算值が実測值よりも小さくなっている。この理由とし ては，上記のプルアウト試験やマイクロボンド試験では 瀻維の引き抜きに伴って, 界面のみが変形するだけでな く，周りの樹脂も変形を受ける。このため，ばね定数と しては小さな值が見積もられ, これにより低い弾性率が 計算されたと考える.しかし, 界面のみの変形量（正確 には, 母材物性で表すことのできない中間層も含めた変 形量）を得ることは上記の試験では難しく，他の方法も 見当たらない。そこで, Yang らおよび Mader らの実験 結果において, 繊維の引き抜き量全体に対して, 界面層 (以後, 中間層も含めた界面領域を指す) での変位は任意 の比率で生じると仮定して, その比率と弾性率の関係を 調べた. 界面層の比率を考慮した弾性率計算の結果を Fig. 6 亿示す.ここで, 例えば比率 5\% が意味するところ は，5\%の変位が界面層で生じ, 残り $95 \%$ の変位が母材 樹脂で生じるというものである. Fig. 6 より, この比率 

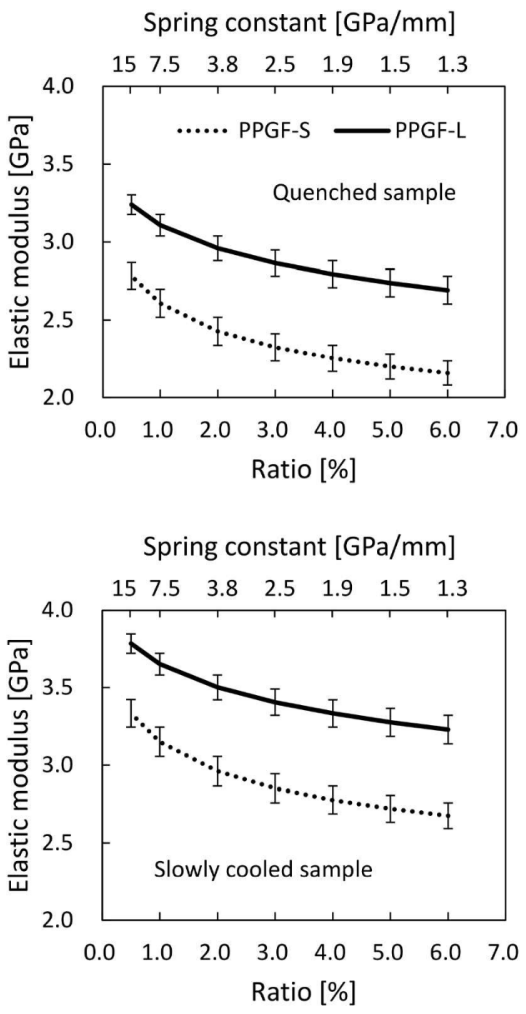

Fig. 6 Dependence of elastic moduli on the ratio of displacement in interface area to that in matrix area.

が小さくなるに従って, 界面層での変位が小さくなるた め，これに応じて弾性率が高くなることが分かる．この 傾向は繊維の長さおよびサンプルに依らず，ほぼ同様で ある。そこで次に，Fig. 6 の結果と実測值を比較した (Fig. 7).ここで, Fig. 6 の結果からは, いずれのサンプ ルでも繊維長が短い場合に実測值に近づくように計算值 を選択した。具体的には，急冷サンプルでは本比率が 0.5\% (界面のばね定数が $15 \mathrm{GPa} / \mathrm{mm}$ ) の結果を選択し, 徐冷サンプルでは本比率が $2.0 \%$ （界面のばね定数が 3.8 $\mathrm{GPa} / \mathrm{mm})$ の結果を選んだ。これらの比率の妥当性につ いては，それに対応する実験データがないために正確な 判断は難しい。しかし，実測サンプルの作製で用いた繊 維強化樹脂は市販品であり, 樹脂と繊維の界面では良好 な相互作用が実現されていると考えられる。このため, 界面層での変位量はさほど大きくなく，0.5\%および 2. $0 \%$ という值は概ね妥当な比率ではないかと考える.

また，冷却条件によって界面層の比率が異なる妥当性 については, 次のように考える。Zhouら ${ }^{28)}$ はポリプロ

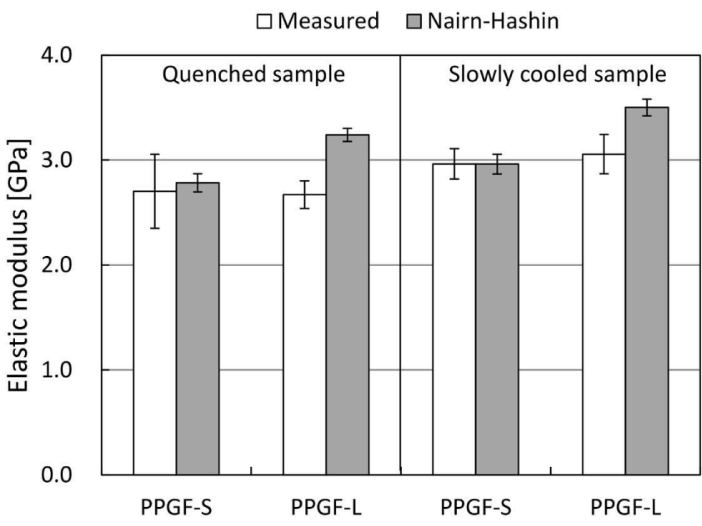

Fig. 7 Comparison of measured and calculated elastic moduli. The calculated ones are obtained using imperfect interface parameters revised.

ピレンとガラス単繊維を用いたフラグメンテーション試 験より，徐冷サンプルの界面せん断強度が急冷サンプル のものよりも小さくなることを報告している。そして, その理由として, 母材 PP の分子鎖と繊維表面にある無 水マレイン酸変性 PP の分子鎖の相互侵入（絡み合い） が, 徐冷サンプルでは冷却時の分子運動で緩和され, 母 材と界面層の相互作用が弱まっているためと考察してい る. 本研究で使用している材料のガラス繊維で表面処理 に無水マレイン酸変性 PP を用いているかは市販品のた め不明であるが，何らかの表面処理剤が使用されている と考えられる。そこで, 本研究の徐冷サンプルでも同様 に，母材 PP 分子と表面処理剂の分子との相互作用が弱 まっていると考えると, 界面層では変形しやすく, ばね 定数としては小さな值となる。 そして, 小さなばね定数 は大きな界面変位量の比率に相当するので，これにより 徐冷サンプルにて本比率が大きくなるものと考えられ る.

さて Fig. 7 より, いずれの冷却条件でも, 実測值に比 べ計算值にて繊維長による差が大きく出ている．計算で は繊維は直線であると仮定され, 繊維の湾曲があると弾 性率は実測よりも高く計算される。このため, 䋊維長が 長い試料では湾曲した繊維が増えて弾性率が高く計算さ れ, その結果, 繊維長による差が大きく出たのではない かと考える.

\section{5. 結言}

本研究では, 短繊維強化の熱可塑性樹脂複合材料の等 価剛性予測に対して, 界面の不完全接着を考慮できる力 
学モデルとして Nairn-Hashin モデルを取り上げ，その 予測性能を評価した。その結果，以下の知見を得た。

(1) 本モデルにて，繊維/母材界面の完全接着を仮定し て計算した弾性率は, Mori-Tanaka 理論より得られ た弾性率とほぼ同等であった。

（2）ガラス繊維強化ポリプロピレンを対象に，単繊維の 引き抜き試験の結果より, 界面の不完全接着を表すば ね定数を推定し, その值を用いて本モデルにて弾性率 を計算した。計算した弾性率は, 引張試験より得た弾 性率の実測值をほぼ表すことができた。

\section{参 考 文 献}

1) 高橋 淳, 鵜澤 潔, 松尾 剛, 山根正睦: 未来材 料, 13, 1 (2013), 36-41.

2) 米山 猛：型技術，30, 5 (2015), 18-22.

3) Y. Pang, X. Dong, X. Zhang, K. Liu, E. Chen, C.C. Han \& D. Wang: Polymer, 49 (2008), 2568-2577.

4) M. Avella, E. Martuscelli, C. Sellitti \& E. Garagnani: J. Mater. Sci., 22 (1987), 3185-3193.

5) M. Akay \& D. Barkley : J. Mater. Sci., 26 (1991), 2731-2742.

6) H.F. Wu, D.W. Dwight \& N.T. Huff: Compos. Sci. Technol., 57 (1997), 975-983.

7) J.L. Thomason \& G.E. Schoolenberg : Composites, 25, 3 (1994), 197-203.

8) C.L. Tucker III \& E. Liang: Compos. Sci. Technol., 59 (1999), 655-671.

9) T. Mori \& K. Tanaka : Acta Metall., 21 (1973), 571-574.

10) G. Lielens, P. Pirotte, A. Couniot, F. Dupret \& R. Keunings: Compos. Part A Appl. Sci. Manuf., 29, 1-2 (1998), 63-70.
11) Y.H. Zhao \& G.J. Weng : Int. J. Solids Struct., 34, 4 (1997), 493-507.

12) J. Fitoussi, N. Bourgeois, G. Guo \& D. Baptiste : Comp. Mater. Sci., 5 (1996), 87-100.

13) J.D. Eshelby: P. Roy. Soc. A-Math. Phy., 241, 1226 (1957), 376-396.

14) A. Jain, Y. Abdin, W.V. Paepegem, I. Verpoest \& S.V. Lomov : Compos. Struct., 131 (2015), 692-706.

15) J.A. Nairn \& M.S. Mohammadi : Compos. Part $A$ Appl. Sci. Manuf., 77 (2015), 26-36.

16) Z. Hashin: Mech. Mater., 8 (1990), 333-348.

17) S.Y. Fu \& B. Lauke: Compos. Sci. Technol., 58 (1998), 389-400.

18）高木謙行，佐々木平三：プラスチック材料講座 [7] ポリプロピレン樹脂 (第 3 版), 日刊工業新聞社, 東 京 (1974), p. 56.

19）高橋秀郎：博士論文（京都大学）（1990）， p. 52.

20) Q. Zia, H.J. Radusch \& R. Androsch : Polym. Bull., 63 (2009), 755-771.

21）大久保信明, 吉田博久：熱測定， 21, 2 (1994), 5560.

22) J.L. Thomason \& A.A. Van Rooyen: J. Mater. Sci., 27 (1992), 889-896.

23）左納武蔵, 角五正弘：高分子，37, 11 (1988), 808809.

24) J.L. Thomason: Compos. Part A Appl. Sci. Manuf., 33 (2002), 1283-1288.

25) F. Garesci \& S. Fliegener: Compos. Sci. Technol., 85 (2013), 142-147.

26) L. Yang, J.L. Thomason \& W. Zhu: Compos. Part A Appl. Sci. Manuf., 42 (2011), 1293-1300.

27) E. Mader \& K.H. Freitag:Composites, 21, 5 (1990), 397-402.

28) X. Zhou, G. Dai, W. Guo \& Q. Lin: J. Appl. Polym. Sci., 76 (2000), 1359-1365. 